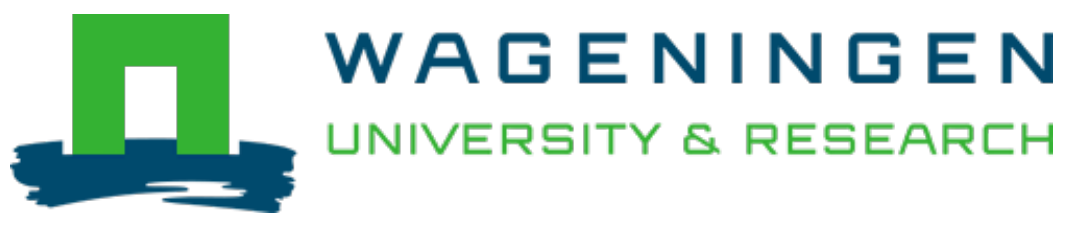

\title{
Pakistan's representation of transboundary water as a security issue
}

International Journal of Water Resources Development

Rigi, Hanifeh; Warner, Jeroen F.

https://doi.org/10.1080/07900627.2020.1870937

This publication is made publicly available in the institutional repository of Wageningen University and Research, under the terms of article $25 \mathrm{fa}$ of the Dutch Copyright Act, also known as the Amendment Taverne. This has been done with explicit consent by the author.

Article $25 \mathrm{fa}$ states that the author of a short scientific work funded either wholly or partially by Dutch public funds is entitled to make that work publicly available for no consideration following a reasonable period of time after the work was first published, provided that clear reference is made to the source of the first publication of the work.

This publication is distributed under The Association of Universities in the Netherlands (VSNU) 'Article $25 \mathrm{fa}$ implementation' project. In this project research outputs of researchers employed by Dutch Universities that comply with the legal requirements of Article $25 \mathrm{fa}$ of the Dutch Copyright Act are distributed online and free of cost or other barriers in institutional repositories. Research outputs are distributed six months after their first online publication in the original published version and with proper attribution to the source of the original publication.

You are permitted to download and use the publication for personal purposes. All rights remain with the author(s) and / or copyright owner(s) of this work. Any use of the publication or parts of it other than authorised under article $25 \mathrm{fa}$ of the Dutch Copyright act is prohibited. Wageningen University \& Research and the author(s) of this publication shall not be held responsible or liable for any damages resulting from your (re)use of this publication.

For questions regarding the public availability of this publication please contact openscience.library@wur.nl 


\section{Pakistan's representation of transboundary water as a security issue}

\section{Hanifeh Rigi \& Jeroen F. Warner}

To cite this article: Hanifeh Rigi \& Jeroen F. Warner (2021): Pakistan's representation of transboundary water as a security issue, International Journal of Water Resources Development, DOI: $10.1080 / 07900627.2020 .1870937$

To link to this article: https://doi.org/10.1080/07900627.2020.1870937

\section{Published online: 12 Feb 2021.}

Submit your article to this journal ¿

\section{Џ Article views: 48}

Q View related articles $\longleftarrow$

View Crossmark data ¿ 


\title{
Pakistan's representation of transboundary water as a security issue
}

\author{
Hanifeh Rigi and Jeroen F. Warner (D) \\ aDepartment of International Relations, University of Tehran, Tehran, Iran; ${ }^{b}$ Department of Social Sciences, \\ Wageningen University, Wageningen, the Netherlands
}

\begin{abstract}
The South Asia region is one of the most unstable in the world, having experienced multiple wars. In recent years, water disputes have intensified between this region's countries, including Pakistan and India, as water is intertwined with their security and has been securitized. Indeed, securitization is one of the strategies that has the power of representation of water as a security issue. The study examines how Pakistan has represented the Indus transboundary waters as a security issue through linguistic constructs, especially to motivate domestic audiences.
\end{abstract}

\section{ARTICLE HISTORY}

Received 8 June 2020

Accepted 22 December 2020

\section{KEYWORDS}

India; Indus; Pakistan; securitization; transboundary water

\section{Introduction}

In South Asia, transboundary rivers are not just regarded as the main sources of irrigation, drinking water and hydroelectricity, but as a crucial factor for development. As a result, water is easily politicized in the South Asia region, and water issues are widely considered as issues related to national security (Price et al., 2014). With the division of the subcontinent into two separate states, India and Pakistan, in 1947, disputes began over the six rivers (Beas, Ravi, Sutlej, Indus, Chenab and Jhelum) crossing through the two countries (Wirsing, 2008). After several rounds of bilateral talks, the Indus Agreement was concluded between India and Pakistan with World Bank mediation in the 1960s. It awarded the control of the eastern rivers (Beas, Ravi and Sutlej) to India and the western rivers (Indus, Chenab and Jhelum) to Pakistan. Since India is upstream, some legal restrictions based on the Indus water treaty were placed on its capacity to change the flow of these rivers (Briscoe, 2010). However, despite the treaty, the two states continued to have disputes in the water realm. In recent decades, their water conflicts have intensified as both countries related water, especially the Indus, to their national security.

In transboundary basins, downstreamers find themselves at a structural disadvantage with respect to upstreamers, especially when the latter embark on dam-building drives. This paper zooms in on how downstream Pakistan, embroiled in (geo)political disputes with its upstream neighbour India, has represented the transboundary Indus waters as a security concern.

The main argument in this paper is that linguistic constructs that link water to national security, including narratives, framings, stereotypes and metaphors (Fischhendler, 2015), 
have played major roles as mobilizing discursive tools: in the representation of Indus waters as a national security issue and infrastructural projects as threats. This contribution shows the role of linguistic tools on water interactions between the countries, shaping the emotions (quite apart from their truthfulness) in a particular (home) audience. We think it relevant to include public 'hate speech' here, which, according to Waldron (2012), is about threatening the lives, dignity and reputations of the targeted groups. Barendt (2019), in a critical review of Waldron's (2012) publication, interpreted Waldron's argument as hate speech doing performative work, as language changing social reality. We will follow this performative interpretation of hate speech addressing a neighbouring country.

While seemingly primarily intended for domestic consumption, belligerent public statements easily spill over into the diplomatic relations between the two countries. While (hydro-)diplomacy is usually associated with peace-making and civility, that is not the only form transboundary communication takes, whether behind closed doors or in public diplomacy. 'Diplomacy can also be aggressive, offensive, antagonistic, hostile, coercive and manipulative' (Faizullaev, 2017, p. 5).

The remainder of the paper is structured as follows. We will first discuss a conceptual framework that focuses on the securitization of water shared between the two countries, and how infrastructure can become a source of this security threat. We then sketch why water is such a sensitive issue for downstream Pakistan. The paper then presents its findings through an analysis of the speeches and statements of various actors involved in the field. This is followed by a discussion and conclusions.

\section{Framing water scarcity and flooding as a security concern}

To reach or legitimize specific goals and values, social actors will try to use discursive strategies. They participate in strategic labelling and making of narratives to sell, legitimize or justify a specific policy or management strategy. Policy-makers use a frame that can further their objectives to induce policy change or policy success (Lindseth, 2005).

'Framing' is defined as a cognitive process that individuals and groups restrict to their perception and analysis of a special event 'in ways consistent with their own views' (Fischhendler, 2015, p. 249). Framing produces 'empty', multi-interpretable concepts and fixes these empty signifiers' meaning through the creation of narrative frames to make a certain discourse hegemonic (Warner \& van Buuren, 2011).

Framing uses metaphors that resonate within a specific cultural and social structure. A metaphor is a discursive tool for conceptualizing an abstract experience based on tangible experiences (Lakoff \& Johnson, 1980). According to Lakoff and Johnson (1980), metaphors in public discourse are not created by chance, but are based on mutual interactions with particular cultural and physical environments. These enduring interactions are in fact the empirical foundations from which metaphor can be understood. As metaphors often use 'alarming' language that shows a serious menace (Fischhendler \& Katz, 2013), they play a vital role in linking the language to the conceptions and perceptions of the audience (D'Hanis, 2002).

In the influential Copenhagen School of Security Studies' conceptualization, security frames have a special 'social magic' to lift issues to the top of the agenda. Successfully presenting an issue as life or death, with only one way out, elevates an issue above 'everyday politics' to national emergency and priority. Once an issue is placed in the security domain, 
this impedes giving up sovereignty and encouraging policy integration. Political leaders, bureaucrats, governments, lobbies and pressure groups are considered securitizing actors, that is, who can 'speak security' from a position of authority. 'Securitizing' actors 'securitize' issues when they assert that something existentially threatens them, or the survival of a referent object identified with (Buzan et al., 1998).

\section{Securitization 2.0: foregrounding the audience, tackling securitization theory's Eurocentricity}

Balzacq (2005) was seminal in upgrading and 'sociologising' the Copenhagen School's securitization theory, emphasizing the importance of security practices and context to understand what speech acts will 'land' with which audience. To become legitimized, securitizing speech needs to relate to the 'feelings, needs and interests' of a range of (intended and unintended) audiences as well as the general public (Salter, 2008). Balzacq (2007, p. 79) establishes securitizing practices as 'an identifiable social and technical device embodying a specific threat image through which public action is configured in order to address a security issue'.

Balzacq (2005, p. 171) notes 'many security utterances counter the "rule of sincerity" and the intrinsic power attributed to "security" overlooks the objective context in which security agents are situated'. The strategic approach that aims to define the general rules of an efficient communicative act of security sets it in a configuration of situations, the congruity of which helps securitization to be realized. A speech act, therefore, is not a sufficient condition for securitization:

the conditions underlying the effectuation of securitization fall into at least three sets of factors - audience, context and securitizing agent. In short, the first of these has three components - (i) audience's frame of reference; (ii) its readiness to be convinced, which depends on whether it perceives the securitizing actor as knowing the issue and as trustworthy; and (iii) its ability to grant or deny a formal mandate to public officials. The second set of factors concerns contextual effects on the audience's responsiveness to the securitizing actor's arguments - relevant aspects of the Zeitgeist that influence the listener, and the impact of the immediate situation on the way the securitizing author's sentences are interpreted by the listener. The third set involves the capacity of the securitizing actor to use appropriate words and cogent frames of reference in a given context, in order to win the support of the target audience for political purposes. (p. 192)

To Balzacq, context is of importance in shaping the security discourse and influencing its success: it is between an antecedent powerful set of causes and their influence on interactions that 'securitization' as a historical procedure happens; this includes simultaneous moves providing reinforcing or aversive outcomes for the process of securitization. Focusing on a single factor such as rules of speech acts may not work if there are other elements notably impact on the process. In line with Balzacq, Salter (2008) argues it is not just the 'grammar' of security but also the context that makes speech performative. Therefore, we need to consider the context in which speech lands. The practices and context in which securitizing speech is uttered may be fundamentally different between cases.

Likewise, Wilkinson (2007), Holbraad \& Pedersen (2012) and others have criticized the theory's Eurocentricity, starting from liberal democratic premises, a separation of state 
and society and state authority from religious authority, and 'normal politics' as distinguishable from 'extraordinary/emergency politics' (Sheikh 2018).

In both religious and secular contexts, this attests to the power of incremental practices that, over time, can entrench certain behaviour and condition citizens to accept social outcomes that may be perceived by outsiders as normatively unjust or wrong (Neo, 2020). Outside the West, non-state actors such as religious leaders may be considered powerful, authoritative speakers. Religious securitizations may use different narrative structure than non-religious securitization, which, in the case of radical groups such as the Taliban, may justify offensive rather than defensive reasoning why extraordinary action is required (Sheikh, 2018).

\section{Environmental securitization}

In the environment realm, recently climate change has become a candidate to be a special domain of emergency as a global environmental mega-crisis. While Buzan et al. (1998) argued that the environment is an uncertain domain for securitization, that has not prevented states such as the UK and multilateral bodies such as the United Nations (UN) from securitizing climate change. Climate change discourse is replete with apocalyptic metaphors such as 'global warming' and 'tipping points'. While vivid metaphor may be considered as supportive to an educational wake-up call for an indifferent world (Merchant, 2014), there is a real risk that apocalyptic claims may backfire (Warner \& Boas, 2017). But while some have claimed that securitizing water can also be 'rhetorical attention-getting' (Deudney, 1990), different studies lend weight to the view that the policy goal for states using metaphor is often to secure a reliable supply of natural resources such as water and energy, which is considered crucial for the stability of the economic and the political situation of a community (Fischhendler \& Katz, 2013). A popular security metaphor in this context is 'water war'. 'Wars about water' are still largely fantasies played out in commercial films such as También laLluvia (2010); Wolf (1995) has convincingly shown that wars over water (only) have not broken out for many centuries. 'Water war', however, is a persistent attention-grabbing discursive trope in both academic, political, non-governmental organization (NGO) and media publications. It has made the title or headline of numerous scholarly and journalistic books and articles since the early 1990s, and remains in use today.

Katz (2011) has termed 'water wars' a hydro-political hyperbole, noting that there is no empirically proven 'hydraulic imperative' impelling states to actually go to war over scarce resources. Threats of military action are not normally followed up by actual acts of war, and if violent conflict involves water, that conflict is rarely over water alone. As he notes, India's move on the headwaters of the Indus and land access to the streams of Kashmir is prima facie, but the bite was never as bad as the bark.

\section{Dam development as a security issue}

Rivers have been the object of military strategy: water can be a goal, target or an instrument for attack or defence (the Dutch, for example, have used controlled flooding against foreign invaders), not to mention water bodies sustaining collateral damage (Francis, 2011). Indeed, from ancient times, strategic natural resources have played main roles both as objectives and as weapons in the international dispute. First, the 
construction of dams upstream may affect a water-intensive economy downstream, which may be in an interpreted as a security threat. In relations between hostile states, moreover, upstream countries may (be perceived by downstreamers to) employ water to gain power, and downstream countries mobilize power resources to safeguard the water (Warner, 2004). Their potential ability to inflict damage can easily inspire a downstream threat perception and defensive reaction; Syria's response to Turkish dam-building on the rivers Euphrates and Tigris is an example (Daoudy, 2009). Dams and hydropower installations can be perceived by downstream as a potential strategic weapon for military objectives which may destroy them, even if that scenario would also hurt one's own economy. Due to these perceived perils, dams and water extremes (floods, droughts) may become securitized. Even water data may be securitized when regarded as a classified issue related to 'national security', so that there is no public accessibility of even basic data and information about international rivers (Barua et al., 2018).

Dam construction directly or indirectly affects 'transboundary water interactions' among riparians. Hydraulic projects promote a form of economic development that influences political power relations in transboundary rivers (Nagheeby \& Warner, 2018), as dam construction is (or can be construed as) a way to control and regulate downstream waters and accordingly control hydro-political relationships (Zeitoun \& Warner, 2006).

Hydraulic infrastructure, then, generates or modifies flows of water, which in turn is linked with flows of power and influence (Molle et al., 2009). Therefore, (geo-)political calculus and hydro-nationalism were the main drivers for dam-building, in addition to the economic and social benefits of such infrastructure. So, with the aim of ruling society, the hydraulic mission may become the logic for dam expansion. Despite this fact, it may not necessarily be economic or advantageous to a specific society (Nagheeby \& Warner, 2018).

In the 19th century, large-scale water infrastructure re-emerged as a child of colonialism, with colonial powers in a situation to reshape and reorganize their colonized territories. Most notably in newly independent countries, elites and state officials made efforts to provide the profits of 'development' to their countries. Therefore, they started modernization and development processes by building large-scale water projects such as irrigation schemes and dams which had both economic and geopolitical interests. Indeed, in the past centuries, states can be said to have used water infrastructure as an intentional political strategy to control their people, waters and territories (Molle et al., 2009).

According to Menga $(2015,2016))$, ruling elites erect dams to reinforce national identity, acquire legitimacy and gain the consent of the domestic players. They describe themselves as a symbol of national pride and development, and as a kind of panacea. Indeed, we may observe dams are often named after statesmen, which makes the projects almost unassailable. Dams can be used to show national rise and power, and as a way of exerting political control over minorities living in the dam region or other riparians (Benea \& Onița, 2017).

Likewise, Allouche (2005) identified the phenomenon of 'water nationalism' as one of the main factors of cross-border water conflicts in the Aral Sea, the Jordan River and the Indus River basins. According to Allouche (2010), by making water and water structures part of the national landscape, governments perceive water not only as a natural resource but also as part of their homeland. By constructing a dam against the will of another country, then, a state can create a symbol of its internal cohesion, assert the right to determine the country's destiny, strengthen its rule over water resources and its assertion of national interests (Menga, 2016). 
Generally, state-building and nation-making are among the factors leading riparians to conflicting situations over transboundary water resources. The symbolic and economic centrality of water resources development in state-building has led states to centralize water supply and regulate its ownership, while nation-making over water has acted through a territorialization of water supplies, leading to the appropriation of water resources against other riparian states. In these cases, the government and the population in general resist identifying the character of water resources as transboundary (Allouche, 2005).

\section{Methods}

This research uses a qualitative methodology. Discourse analysis is a way to study how social reality is constructed through discursive process. Language does not mirror 'reality'; instead, it can provide us discursive access to it (Lindahl \& Sundset, 2003). Discourse analysis analyses the way in which semantic systems or discourses shape people's understanding of their role in society and influence their political activities (Torfing, 1999).

Our analysis of the discourse is a macro-analysis of so-called 'speech acts'. The linguist J. L. Austin was the first to claim that 'saying' is essentially 'doing': speech not merely describes social reality but also shapes it; language is performative if it resonates with an audience and triggers a certain response. Saying 'security' elevates an issue into the domain of life-or-death (survival) decisions, legitimizing extraordinary measures. We studied the materials in search of a certain 'security logic' defined by securitization theory. Securitization theory aims at interpreting and understanding something through the eyes of an actor; in our case, that means through the eyes of Pakistani actors.

For present purposes, the analysis of official speeches, and national and international English-language media reports proved useful in analysing Pakistani political actors' discourse. We systematically searched our research data, consisting of different types of news and political 'texts' (articles, documents and English-language news sites) using keyword searches ('Pakistan', 'Indus waters, crisis'). After collecting the raw data, the collected data were analysed for 'metaphors'. Metaphors take aspects of one domain (territory) into another, for example, from the military or security into the water domain. 'Conceptual metaphor as related to emotion constitutes the fundamental argumentative feature and crucial tool to address the matter of persuasion in text, contributing to identifying both the ideological root and the persuasive strategy of a given discourse in the long run' (Ferrari, 2007, p. 603).

Consistent use of metaphor supports the construction of a particular view of world events and government responses to them. Metaphors in political discourse can function like warrants in an argument, strongly linked with argumentation/(de)legitimation in political discourse (Lakoff \& Johnson, 2003, cited in Lorenzo-Dus \& Marsh, 2012).

Thus, 'metaphorical analysis' is a useful tool in establishing a particular discourse and shedding a light on common semantic structures. After observing the repetition of the main themes (saturation), the study of texts stops (Milliken, 1999).

\section{Pakistan's water insecurity}

In recent years, the water security concept has frequently been used in South Asia where (transboundary) rivers, with their potential for hydroelectric projects and agricultural utilization, have been defining intergovernmental relations (Kumar Sinha, 2008). 
Water is strongly bound up with the food security and livelihood security of a large number of agriculture-dependent people. Like Egypt, Pakistan has developed around a single river system (Briscoe, 2010). Almost all Pakistan's areas in the plains, from the Peshawar Valley to the Sindh coastline, are part of a single hydrological system: the Indus Basin, which is indicative of a remarkable geographical feature of Pakistan (Gazdar, 2005). Pakistan has the greatest irrigation system in the world, with 36 million acres of cultivated land, provided by Indus water and its branches. There are three large storage reservoirs, 19 large dams, 12 river canals, 45 independent irrigation canals and 84 small dams in Pakistan (Burgess et al., 2016).

A water crisis can easily be a source of instability for the country. It is therefore deeply concerning for Pakistan to be facing a looming water crisis. A 2010 UN report declared that Pakistan is near to being regarded as a 'water-scarce' nation (Khalid, 2010). Pakistani leaders maintain the country's water security now faces enormous threats. While at Partition, water availability in Pakistan was $5000 \mathrm{~m}^{3} /$ person, today with the population having grown five-fold, water availability is less than $1000 \mathrm{~m}^{3} /$ person, significantly lower than the globally accepted water scarcity threshold (Riffat \& Iftikhar, 2015). However, this does not take into account the (in)efficiency of water management. Like other places, there have been considerable water losses in Pakistan's agricultural and domestic sectors due to the absence of proper management programmes (Bakshi \& Trivedi, 2011).

Pakistan is among the 15 states that receive more than $75 \%$ water from outside sources (Qadir, 2008). The Indus is the lifeline of Pakistan's agrarian economy; hundreds of thousands of acres of fertile land in both Punjab and Sindh provinces are dependent on it (Mirza, 2016). Water is vital for producing and harvesting food crops, and farmers form the core pressure group (Burgess et al., 2016).

However, we will define here the concept of water scarcity more broadly; it means not only physical threats such as water scarcity or flooding, but also the political dimension of these threats is of great importance. However, this political aspect, based on emphasizing differences, inequalities and struggles between different groups, can take different forms (Selby, 2003).

Water has been securitized in different ways in South Asia, for example, India has securitized its shared water with Nepal through pragmatic practices (Mirumachi, 2013). But water security is especially salient in Indo-Pakistan relations, where they are bound up with the Kashmir (short for Jammu and Kashmir - J\&K) issue.

\section{The Kashmir issue}

Pakistan and India are neighbours with complicated ideological, historical and geopolitical problems that cannot be simply removed or be forcefully solved (SugunaKararaju \& Akhtar, 2015). Both India and Pakistan have held their opposite number responsible for the disputes between them. For example, General Kathpalia, a former Director of Military Intelligence of the Indian army, declared the Pakistani leaders responsible for the 'psychological' origin of the conflict between India and Pakistan (Cohen, 2001). These mutual perceptions that stem from their (geo)political disputes between the two countries have increased tensions between the two sides and are seen in their water relations which contributed to the securitization of water in the region. 
From a geopolitical viewpoint, Kashmir has gained a unique position on the Indian subcontinent since the 19th century. With its common border with the Central Asian republics, Afghanistan, Pakistan, China and Tibet, Kashmir has acquired special significance. Thus, by occupying northern Kashmir, Pakistan has gained great strategic gains in South Asia, too. In the minds of the Indians and Pakistanis, the Kashmir issue has become the biggest concern facing the Indian subcontinent (Kalis \& Dar, 2013)

The Indus criss-crosses Kashmir: after originating from the Indus Basin in Kashmir, the rivers enter into Pakistan and flows there (Masood, 2010). Therefore, this river is of considerable geostrategic significance for both countries because it supports their water requirement and demands. Moreover, the Indus main branches, such as the Jhelum and Chenab, are regarded as an especial concern for relations between the two sides because their headwaters lie in the disputed areas of Kashmir (Wescoat et al., 2000).

Since the three major rivers in the Indus system - Indus, Jhelum and Chenab - pass through Kashmir before they enter Pakistan, the Kashmir dispute is inseparable from international politics of the Indus. Controlling the territory of Kashmir, therefore, is not merely due to religious sentiments, but also the control of its freshwater, which is a great advantage for riparian areas dependent on irrigated agriculture (Akhter, 2016). As a result, control of the rivers provides one side a condition to put pressure on the other. Pakistan's former Prime minister, Liaquat Ali Khan, in 1947, claimed that 'the security of Pakistan is bound up with that of Kashmir' (Cheema, 2015). Briefly, control over the Kashmir state means the control of the 'India and Pakistan's water valve', too (Rivière, 2015). Since 1947, wresting the Kashmir area from India has been the main goal of Islamabad's foreign policy vis-à-vis Delhi (James \& Özdamar, 2005).

\section{Results}

\section{Kashmir}

The main framing of Pakistan's water security is clearly in connection with 'Kashmir', so that most Pakistani politicians, military and academic scholars frame water security in connection with this region (Bisht, 2011). Sardar Sikandar Hayat, who was J\&K prime minister twice, has often stated: 'The freedom fighters of Kashmir are in reality fighting for Pakistan's water security and have prevented India from constructing a dam on the Wullar barrage' (Kumar Sinha, 2008, p. 963). According to Sardar Mohamad Anwar Khan, former president of J\&K, 'Pakistanis who believe that they can survive without Kashmir are wrong. The Pakistani economy is dependent on agriculture and hence on water, and therefore on Kashmir.' Along similar lines, Syed Salahuddin, chairman of the United Jihad Council, said, 'Kashmir is the source from where all of Pakistan's water resources originate. If Pakistan loses its battle against India, it will become a desert' (Kumar Sinha, 2008, p. 963). The Pakistani politicians' statements represent a catastrophic status, meaning losing Kashmir would lead to the country's water insecurity, which can be regarded as an existential threat to Pakistan.

Pakistan's water security linkage with Kashmir forms part of the Pakistani water discourse in which India has been the main source of Pakistan's water supply shortfall. Many Pakistani politicians, authorities and media have linked the water to the Kashmir dispute and to their perception of India. For example, Waris Khalo, member of the Punjab Assembly, stated that as long as the Kashmir dispute and water issues are not 
resolved, India would 'remain an enemy' (Gupta, 2010). Further, the India trade transit facility was rejected through a resolution passed by members of the Punjab Assembly; they pledged to deny it until the Kashmir dispute and water issues be resolved. General Ashfaq Kayani regarded water and Kashmir issues as unresolved issues with India, stating that 'India will remain the focus of Pakistani military doctrine so long as Pakistan has unresolved issues with India' (Gupta, 2010). Also, Asif Ali Zardari, Pakistan former president, stated: 'The water crisis in Pakistan is directly linked to relations with India. Resolution could prevent an environmental catastrophe in South Asia, but failure to do so could fuel the fires of discontent that lead to extremism and terrorism' (The Telegraph, 2009). By linking water scarcity to the history of hostility of his country with India, Zardari as a securitizing actor sought to interpret water security in conjunction with Pakistan's perpetual enemy: India. Thus, he created a security plan based on an existential threat associated with 'terrorism', a top priority in security issues, not only in Pakistan but also in the whole region. The implication is that Indian water activities are dangerous to the entire region.

Further, Riaz Haq, founder and president of Pak Alumni Worldwide, has made a connection between water and terrorism, claiming that in Pakistan there is a concerning growth in social dissatisfaction, terrorism and instability as possible consequences of water shortage leading to crop failure and poverty (Romshoo, 2012).

These articulations have been created by Pakistan, while India has frequently blamed this country for sheltering terrorists in its homeland (Osiur, 2015), and financial aid to Pakistan had been suspended by the United States due to Islamabad's failure to take serious action against terrorist groups (Khattak, 2018). Therefore, if Pakistan succeeded in escalating the Indus water issue to the level of a national security threat, it would be a chance for the country to justify Islamic groups' violence in Kashmir as a counter to India's water threat on the Indus for Pakistan.

\section{Fearing diversion}

Fifty years ago, the former chairman of the Tennessee Valley Authority, Lilienthal, announced:

No army, with bombs and shellfire, could devastate a land as thoroughly Pakistan could be devastated by the simple expedient of India's permanently shutting off the sources of water that keep the fields and people of Pakistan alive. (Kraska, 2003, p. 482)

Pakistani officials have often called India to account about this concern. For example, in 2008, on the sidelines of the UN General Assembly, Asif Ali Zardari raised the water problem with India's prime minister, Manmohan Singh. He told Singh that India's water diversion from the Chenab River impacted adversely on Pakistan agriculture. According to media, Islamabad called for Indian officials to compensate for Pakistan's loss of agriculture due to India's water activities (Gupta, 2010).

Water diversion or interruption has created a threat perception in Pakistan. In Pakistan, this threat perception is linked to 1948, when India locked the water canals on the eastern rivers of Ravi and Sutlej and only after the agreement of May 1948 agreed to open the flow of water again (Hill, 2006). Pakistan's misgivings about Indian intentions were intensified by an article entitled 'How strong is Pakistan?', published in Vigil (Delhi) on 8 August 1951. In It, Indian officials challenged Pakistan's national power and sovereignty: 
though Pakistan has one of the largest irrigation systems in the world, she is entirely dependent for water on the rivers of East Punjab and Kashmir. If India were to cut off the waters, it is bound to impair Pakistan's strength considerably. Even her very existence could be in danger. Whether India would adopt such a perfectly legitimate but ruthless attitude without grave provocations is another matter. Pakistan produces plenty of food but that production depends on canal water which in a sense is a gift of India and is in her power to stop.(Mirza, 2016)

According to the famous diplomat Josef Korbel, a member of the UN's Commission on India and Pakistan (UNCIP), as cited in Wirsing (2008), if India's troops in 1948 had been able to 'grab' the lower waters of the three rivers - Indus, Jhelum, Chenab - flowing into Kashmir on their way to Pakistan, India would have achieved an opportunity to choke off Pakistan's economy:

This economic threat was highly important in the minds of the Pakistani leaders. [...] The occupation of these rivers and their dams by the Indian army and the eventual diversion of their waters through canals would have meant Pakistan's quick economic death. (Wirsing, 2008, p. 7)

The threat perception due to water diversion continues to be reflected in the statements of politicians, academics and media literature of Pakistan.

In this context, engineer Fatehullah Khan Gandapur, former chairman of the Indus River System Authority, referring to the diversion of the Indus by India, implicitly described water as a 'weapon of mass destruction' that India utilizes to turn Pakistan into a 'desert' (Baqai, 2017). Weapons of mass destruction evoke 'fears of chemical, biological, or even nuclear attacks' (Heradstveit \& Bonham, 2007, p. 423). Introducing water as a weapon of mass destruction poses a negative security burden and places it at the centre of the country's security and existential threats, even if water as a weapon of mass destruction is used in the political rather than the technical sense.

Also, Senator Rahman Malik stated in 2018:

Blocking of water reminds us of Karbala and Modi by blocking of water wants to deprive Pakistan of water to convert her into desert. In fact, Modi is following a full-fledged anti Pakistan agenda. Initially he got Pakistan diplomatically isolated, developed closer relations with USA at the cost of Pakistan, created close network with Afghanistan to get more pressure on western boarders [...]. (Malik, 2018)

The word 'Karbala' in Senator Malik's statement is of special meaning among Muslims, with whom the Karbala event resonates as one of the most tragic events in Muslim history. With these remarks, the senator invoked the time when (Caliph) Yazid cut off the water flow against (Imam) Hussein in 680, to the diversion of Indus water. According to Nakash (1993, p. 162), in Shi'is view, Hussein's martyrdom in Karbala 'was a symbol of sacrifice in the struggle (jihad) for right against wrong, and for justice and truth against wrongdoing' and lies. Corresponding Indian water activities to a tragic religious event would create a negative burden in society. Therefore, there is an articulation among concepts of '(Imam) Hussein' Yazid, Islam, water and India (Hindus). Indeed, here religious articulation identifies how an ownness community creates, leading to the production and reproduction of hidden political actions in this process. 


\section{Water infrastructure construction as 'water theft'}

The discourse of water 'ownership', a sign of rejecting the international character of transboundary river basins, has been frequently used and expressed by both India and Pakistan. In line with this discourse, water is considered part of the motherlands of both sides, and the metaphor of 'water theft' resonates in this mindset.

India reconfirmed its imputed ownership of Indus water, for example, in 2016, when the Indian prime minister stated at the inauguration of the All India Institute of Medical Sciences Bathinda that, 'Water that belongs to India cannot be allowed to go to Pakistan' (Dawn, 2016). Also, on 25 November, he claimed the ownership of Indus waters, saying, 'waters of Sutlej, Beas and Ravi rivers 'rightfully' belong[ing] to India will be stopped from going [to] "waste" in Pakistan' (Assam Tribune, 2016).

In this context, the main current water disputes in the region concern the construction of dams, storage and water diversion. Pakistan has disputes with India over its construction of dams on the western rivers before they enter Pakistan. Many Indian projects on the Indus, in particular, the Kishanganga Dam (330 MW), Baglihar Dam (850 MW) and the Tulbul project, known in Pakistan as the Wullar Dam, have been a source of concern for Pakistanis, and Pakistan has called these projects a violation of the Indus Agreement (Riffat \& Iftikhar, 2015).

Pakistan has tied Indian dams and water projects to hostile intentions of India and accused India of 'stealing' its water (Sharma, 2012). In Pakistan's view, Indian dam-building and water projects in strategic areas are to increase India's and reduce Pakistan's influence over the regions. Pakistani officials claim that owing to the lack of energy capacity in the Kashmir, Indian hydroelectric projects, including the Baglihar Dam, are very useful tools for India to gain political support in Kashmir, and to expand the gap between Kashmiris and Pakistanis (Wirsing \& Jasparro, 2007). Pakistan claims that India has been trying to tie its influence and stability to Kashmiris' access to hydroelectric through dam-building. Here, the link between the two concepts of Kashmir and dam is found in Pakistani's dialogue. According to Islamabad, by creating hydroelectricity projects, India wants to enhance its dominance over Kashmir and portray Pakistan as a state that acts against the interests of Kashmir, seeking to alienate Kashmiris from Pakistan (Mazari, 2005). Thereby it purportedly causes the diminishing of Pakistani identity in these areas, a problem related to the country's nation-building process.

Indeed, any change in Kashmir's waters in favour of India is considered a threat to Pakistan's national security which contributed to securitization of water.

\section{The 'water bomb' metaphor}

Another trigger that shapes the threat perception of these countries leading to securitization of water is intentional flooding policy. During the 2010 monsoon season, for example, flooding in Pakistan cost billions of dollars and harmed both the people and the government. Damage to food products and degradation of property had an adverse impact on overall economic performance and had also deteriorated current government account deficits which increased the pressure on the Pakistani government and increased its debt (Looney, 2012).

Pakistan considered the unexpected release of waters into the rivers that flow from India to Pakistan as instrumental to India's attempt to put pressure on Pakistan (Nadeem 
et al., 2019). Pakistani statesmen and politicians have repeatedly invoked a narrative of intentional release of water by India (Malik \& Tanveer, 2014). Islamabad reportedly considered the unexpected release of water from India to Pakistan as India waging 'fifth-generation warfare' (5GW) (i.e. a propaganda and information warfare) on Pakistan (Reuters, 2019).

A significant feature of $5 \mathrm{GW}$ is that the target has already lost that war as it may not even be aware of having been attacked. Also, the target cannot measure the damage (Abbott, 2010). Therefore, Pakistan's use of the ' $5 G W$ ' term carries a connotation of fear and a security burden, which can have a strong effect on its own society or even on international society.

Further, both flooding and diversion of water have been termed a 'water bomb' strategy. The 'water bomb' illustrates the depth of the disaster threat and the extent of the vulnerability of a country from sources such as water. For these countries, both the flood and the cutting off of water will damage agricultural production; posing challenges to an economy of a country based on agriculture will raise instability inside that country.

From a Pakistani point of view, India used the 'water bomb' strategy to put pressure on Pakistan and hit Pakistan's economy (Baqai, 2017; Malik \& Tanveer, 2014; Wellen, 2011). Pakistan believes that as India has not accepted the separation of Pakistan, it is hopeful to regain it, so the weakness of Pakistan has always been its aim (Maqbool \& Alam, 2016). Thus, damage to the economy of a country is one of the ways to weaken it.

According to the former Interior Minister of Pakistan, Senator Malik: '[India's] PM Modi has created now a water bomb for Pakistan and the first water bomb has been thrown on Pakistan by blocking of our legitimate natural watercourse' (Malik, 2018).

In 2008, an editorial in the Roznama Ausaf newspaper had already accused India of using a 'water bomb' strategy to choke off Pakistan's economy. According to the article, officials in Pakistan's Indus Basin Water Council (IBWC) claimed that what India could not get through wars (with Pakistan) during the past six decades it wanted to attain through dropping a 'water bomb'. They also noted that India was planning '50 dams to raid the waters of the rivers' running into Pakistan, and then warned: 'If this is not foiled, Pakistan will face the worst famine and economic disaster' (Wellen, 2011). In this context we call attention to Mustafa's observation that on the physical risk-management side, flood control has been a secondary thought related to physical risk and exposure reduction, while irrigation in Pakistan and generating electric power has been the prime concern for dam and barrage management in this country (Mustafa, 1998). Reflecting this thinking, Syed Mahmud Nasir, Pakistan's Inspector General of Forests at the Ministry of Climate Change, noted, 'We have the water and power authority that thinks only dams are needed and the disaster management authority just gives out bags of rice and flour during every disaster' (Ebrahim, 2015).

Further, infrastructure such as dams and other water projects are regarded as coordinated efforts to strengthen the preparedness of the armed forces of the rival country (Rahman, 2014). According to anti-Indian discourse in Pakistan, there is a strategic goal behind the construction of the dam by India. The anti-Indian group has repeatedly stated that controlling water through massive dam-building gives India a strategic position that can be used in a military conflict with Pakistan: it would enable India to flood the battleground and canals or close the dams' gates to make Pakistan's canal system dry so that it can pass its forces easily and make Pakistani troops retreat (Singh, 2008). For 
example, Pakistan is concerned that the construction of the Wullar Barrage provides India with an opportunity to use it during wartime. Pakistan worries that India will use these water projects on the western rivers as a bargaining chip to settle other related issues or exercise 'hydro-hegemony' on these water schemes. However, India rejects these claims as it cannot flood Pakistan without flooding its own territory first (Nazakat Ali \& Faiz-UrRehman, 2015).

From Pakistan's point of view, the Baglihar Dam is also of great importance, providing India with the tools not only to exert pressure on Pakistan economically but also to flood it for the military objective (Wirsing \& Jasparro, 2007).

This line of thinking is embedded in Pakistan's military culture. Water canals in Pakistan are also built for defence purposes (i.e., the Bambanwala Ravi Bedian Communication canal). Several of these 'defence canals', including the Upper and Lower Chenab canals, have been constructed at strategic places to be used during war and tension periods to prevent the passage of India's forces (Figure 1). In 2002, after the attack on the Indian Parliament on 13 December 2001, when India mobilized its troops, Pakistan decided to transfer the waters into these defensive canals to prevent India's attack on water flows (Bisht, 2011). Hence, one of the factors behind the threat perception of India's water projects is that Pakistanis are worried India would flood Pakistan during war or tensions periods.

Pakistani analysts have called India's water projects on the Indus way more dangerous than one 'nuclear bomb'. They claimed the Salal Dam, constructed in the late 1970s at the Chenab in Dhiangarh, and the Marhu Tunnel, a transfer water project, to divert water from

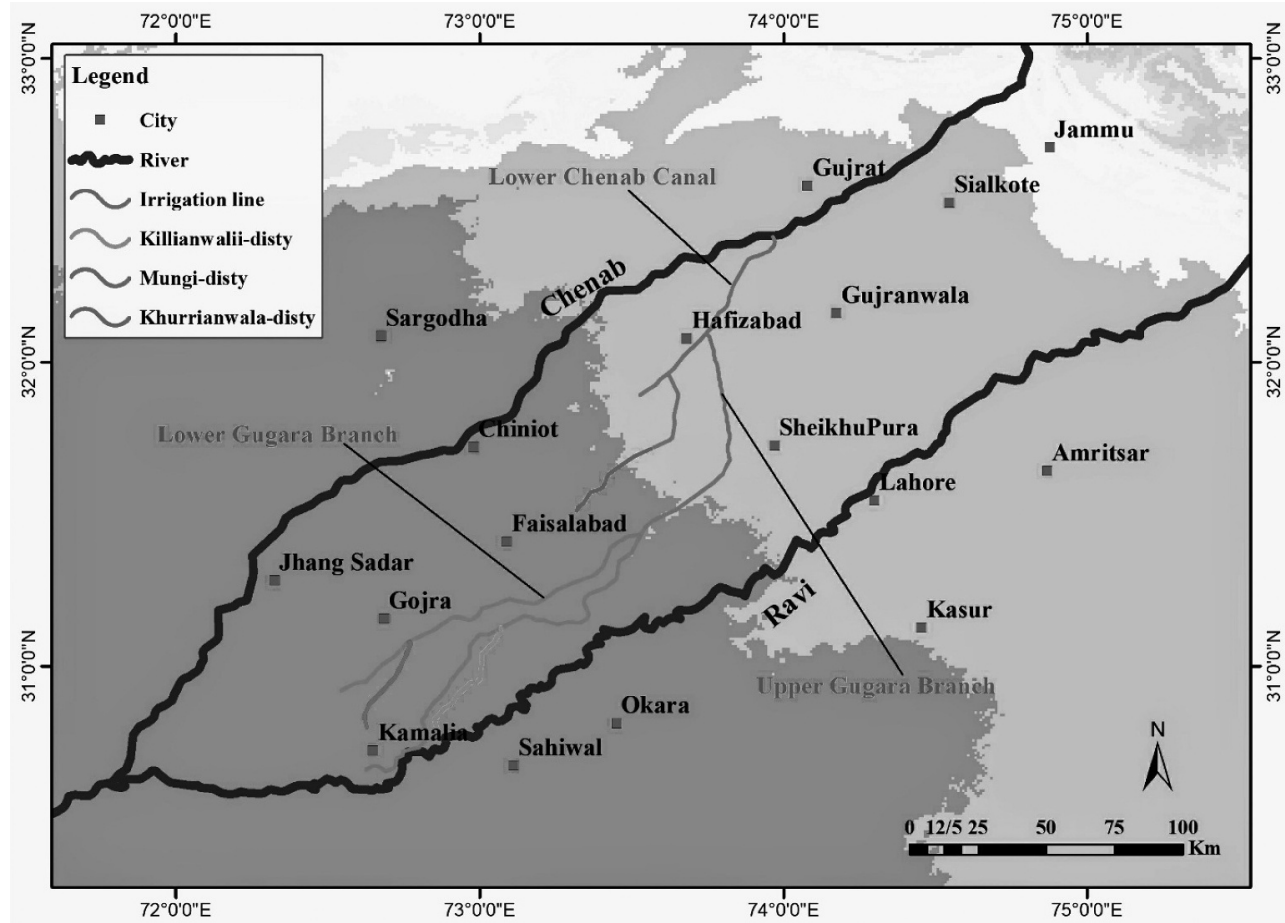

Figure 1. Location of the Chenab canals. 
Chenab to other Indus tributaries such as the Ravi, Beas and Sutlej, provide an opportunity for India to turn Punjab's fertile fields into a desert, or by flooding to completely eradicate the agriculture of Pakistan where the lives of millions of farmers as well as their property in Punjab depends on agriculture and water (Mirza, 2016).

In May 2009, Hafiz Zahoorul Hassan, IBWC chairman claimed, 'India's water terrorism is a bigger threat than Talibani terrorism,' and then he continued:

The day is not far when circumstances like those in Somalia, Ethiopia and Chad will emerge inside Pakistan [...] India has readied a weapon for use against Pakistan that is more dangerous and destructive than an atomic bomb. (Wellen, 2011)

Moreover, National Assembly member Palawash Khan has also accused Delhi of committing 'water terrorism' against Pakistan, and stated: 'experts foresee war over the water issue in the future and any war in this region would be no less than a nuclear war' (Gupta, 2010). Terrorism is, in the broadest sense, the acts of violence that target civilians to achieve a political or ideological aim: 'criminal acts intended or calculated to provoke a state of terror in the general public, a group of persons or particular persons for political purposes', and that such acts 'are in any circumstances unjustifiable, whatever the considerations of a political, philosophical, ideological, racial, religious or other nature that may be invoked to justify them' (Office of the United Nations High Commissioner for Human Rights, 2008, p. 6). Therefore, considering India's actions in the water realm, 'terrorism' represents India's water activities as unjustifiable violence against Pakistani civilians. Also, it poses a negative security burden and puts it at the centre of Pakistan's security and existential menace.

Jamaat al-Dawa, a Pakistani Islamist group, contributes to the 'war narrative' in the water domain. Hafiz Saeed, founder of Lashkar-e-Taibi and head of Jamaat-ud-Dawah, during a television interview accused India of causing the flood crisis in Pakistan and well threatening a 'water war' with India. He claimed that India uses water as a weapon to weaken Pakistan (Crilly, 2010).

The anti-Indian discourse has been successful in convincing intended audiences of vital Indian water threats towards Pakistan. For example, on 6 September 2010, the Pakistan Muttahida Kissan Mahaz, a farmers' collective considered as the lobby group for Pakistanis farmers too, launched a demonstration with farmers, businessmen, students and civil society members from various cities, including Lahore, Rawalpindi, Vehari and Multan, at the Wagah border post against Indian water infrastructures on western rivers (Dawn, 2009). While accusing India of 'stealing' river waters, Ayub Mayo, chief of the collective, claimed that Pakistan's irrigation system has been adversely affected by India 'stealing water' (Khalid, 2010). He continued:

Chenab is the lifeline of Punjabi farmers. It irrigates 65 to 70 per cent of the land here. There is a big conspiracy to starve the Pakistani population to death [...] We are the biggest stakeholders. We will keep on raising our voices. We will not relent. This is a matter of life and death for us. (Masood, 2010)

Some in Pakistan oppose this perception in the water arena. They believe the problems of water scarcity in general, and the flood events especially in this country, are due to the mismanagement and lack of proper water plans by the Pakistani authorities, more than the fault of India. For example, Shah Mehmood Qureshi, former foreign minister of 
Pakistan, claimed that the wastage of 35 million acre feet (MAF) of water has been caused by Pakistan, and if the seasonal variations occurred it has been due to the 'natural hydrological cycle' (Vaid \& Maini, 2012). Mustafa and Wrathall (2011) claim, however, that the 2010 flood in Pakistan was not an accidental, unforeseeable and unplanned incident in the hydrologic development of the Indus basin, but was a national decision on water use linked to the design of the social landscape.

In 2010, the Punjab Water Council, which represents the farmers of Punjab, emphasized that urgent talks with India were necessary, as Indian water activities could lead to rivers in Pakistan drying up (Bisht, 2011). Talks suggest an opening, and indeed Pakistan's tone changed during the rule of Nawaz Sharif, Pakistan's Prime Minister from 2013 to 2017, who sought to develop Pakistan relations with India to improve the languishing Pakistani economy (Dawn, 2017). In July 2015, for example, Pakistan Senate's Standing Committee on Water and Power held that India was using less than its allocated share in the western rivers under the International Water Treaty and therefore was not responsible for Pakistan's water shortage (Bhushan, 2018).

However, in 2014, Narendra Modi became India's prime minister on a Hindi-nationalist platform, and the aforementioned 'desecuritizing' voices did not prevent him making water threats in response to crises with Pakistan, or issuing announcements of new dam projects on the Indus system just before Indus meetings (Bhushan, 2018). Recently, India directly threatened Pakistan to cut off the flows of water after a suicide attack in Kashmir for which Delhi blamed Islamabad. According to some analysts, this was the strongest threat India has made so far. India's transport minister, Nitin Gadkari, said in a Twitter message: 'Our Govt. has decided to stop our share of water which used to flow to Pakistan. We will divert water from Eastern rivers and supply it to our people in Jammu and Kashmir and Punjab' (Gettleman, 2019). The tweeted threat of upstream infrastructure used as a 'tap' to cause floods or scarcity predictably caused great agitation in downstream states. That does not necessarily mean that such actions are very likely, because stopping water completely will impact not only downstream areas but also upstream agriculture; it harms both Pakistan and Kashmir (Haq \& Sofi, 2019).

\section{Discussion: securitization and felicity}

We have seen several examples of how water moves by India on Pakistan are constructed as threats through speech acts. They have tended to restrict their perception and analysis of India's water activities in ways consistent with their views on India based on a given context, leading to a hegemonic anti-Indian discourse in the water realm through the creation and conflation of Kashmir and water narrative frames. In fact, the threat posed by India is the core signifier in this discourse, formed since the beginning of the partition of India and Pakistan, and has been further articulated with water insecurity.

We identified at least four types of discursive metaphors in Pakistan's political activists' discourse. Table 1 categorizes the discursive metaphors.

To refer to India's water activity as dropping the 'water bomb' is to portray its interventions as a dangerous weapon that poses a serious threat to Pakistanis, while the reference of Karbala is associative of 'the enemy-other' (India), identifying ownness ('us') versus otherness ('them'). Except for 'water theft', which strictly speaking is criminalization, not a securitized (life-and-death) issue, the metaphors used in Pakistani circles listed in Table 1 
Table 1. Discursive metaphors

\begin{tabular}{|c|c|c|c|}
\hline $\begin{array}{l}\text { Metaphor of } \\
\text { environmental } \\
\text { gdiscourse }\end{array}$ & $\begin{array}{l}\text { Metaphor of law } \\
\text { discourse }\end{array}$ & $\begin{array}{l}\text { Metaphor of religious } \\
\text { discourse }\end{array}$ & $\begin{array}{l}\text { Metaphors of war } \\
\text { discourse }\end{array}$ \\
\hline Desert & Water theft & Karbala & $\begin{array}{l}\text { Water bomb } \\
\text { Water war } \\
\text { Water terrorism } \\
\text { Water weapon }\end{array}$ \\
\hline
\end{tabular}

drive feelings and images of near irreversible peril, past and future. Many of the security speech such as metaphor counter the 'rule of Sincerity' (see Balzacq) and they are a metonym for something else. However, metaphor may thus be a 'logical absurdity' (Heradstveit \& Bonham, 2007) but an effective instrument at least for domestic audiences.

Pakistan's people are mostly the referent object, declared at vital risk in Pakistan's water securitizing process. The Pakistani securitizing actors draw attention to the urgency and level of the threat: 'If this [India's dam-building] is not foiled, Pakistan will face the worst famine and economic disaster.' Threat discourse aimed at domestic audience is effective, and as stated above, the farmers and other civil institutions rallied against India's water activities. Belligerent metaphors are used to excite the population, never mind if they make them do stupid things. These metaphors are used to affect the domestic population and make people fear the 'other'. It means hate speech has performativity for Pakistan's domestic audiences picturing the 'other' (India) as an existential threat. However, it is not just the 'grammar' of security speech but also the 'context' that makes speech performative. Within a small context of religious-nationalism which is a part of the larger hostile context between the two countries due to their geopoliticalterritorial conflicts, these metaphors are performative at least for Pakistan's domestic audiences and stir their religious or nationalist identity passions and extreme emotional volatility. Indeed, the metaphors within a given context, whether religious or nationalistic, true or wrong, invoke catastrophes that not only legitimize securitization but also provide an opportunity to create a catastrophe. That justifies the political generation of catastrophe and convinces people to participate in it (Warner, 2013). One main reason for the dispute between India and Pakistan concerned opposing ideologies linked to Indian and Pakistani ideas of state-building. For Indian leaders, their country was a secular state based on civic nationalism, while Pakistani leaders considered their country as an Islamic entity that would serve the requirements of all Muslims in the region (Lee, 2002).

Thus, the role of context is of importance for the success of the securitization process. Using metaphors for war has contributed to conceptualizing water experiences based on all-too-tangible experiences. After all, Pakistan has been at war with India for years (Ganguly \& Lee, 2002), so that both countries have reason to be concerned about each other's nuclear weapons (Dar, 2020). Pakistan has been repeatedly accused of using terrorist groups on Indian soil (Osiur, 2015), and blamed India for fuelling insurgencies in Khyber Pakhtunkhwa and Pakistani Baluchistan (Bhatnagar \& Mohan, 2016). On the other hand, with the increase of its population, this country is very concerned about water shortages. Therefore, by studying these discourses (war, religion, law and environment) and given the different experiences of this country, it can be seen that through metaphors that have created connections between conceptualizing water experiences and other tangible experiences (war, water scarcity, Indian weapons, religion, terrorism), Pakistan 
has been able to lift water from the low to the high politics realm. Indeed, metaphor as hate speech is performative among Pakistan's domestic audiences within the given context which included their objective experiences with India.

While we noted some space for 'shades of grey' emerging from the Pakistani side in the 2010s, Indian statements on threatening the diversion of water flows to Pakistan have made Pakistan's water securitization process extra 'felicitous': when a securitizing move can be documented by external evidence such as hostile sentiments generally perceived as threatening, the security threat is more perceptible (Buzan et al., 1998). Indian belligerent statements on river diversion, however, does not necessarily mean that such actions are very likely, as stopping water wholesale impacts downstream and also upstream agriculture; not only Pakistan is harmed, but Kashmir, too (Haq \& Sofi, 2019). Therefore, the actual implementation of such threats is almost beside the point: the 'affect' on the audience may be enough. Besides, this mechanism only reproduces and reinforces historic perceptions of the other as the mortal enemy, the threat to Pakistan's survival for which military protection is the only remedy.

In 2016, Islamist extremist forces attacked the Uri area in Indian-administered Kashmir. After the attack, India suspended the Indus Commission and announced that she would review the Indus Water Treaty until Pakistan stop supporting such terrorist groups. Pakistan addressed the dispute in the Court of Arbitration (World Bank, December 2016). Also, the Chinese reacted to India's decision and declared it would build a huge dam on one of the Brahmaputra's branches, the Xiabuqu: as India is downstream of the Brahmaputra, whereas China is upstream, this can incite Beijing to act (using an issue linkage strategy) like India acted on the Indus (Kaushik, 2017). Indeed, as the upstream state and also Pakistan's strategic partner, China's implicit threat of retaliation to downstream India nullified the Indian issue-linkage strategy (Rigi \& Warner, 2020). In such a context, it is improbable India would stop water completely.

When threats are presented as a disaster, could there be ulterior, political or moral ends? In displaying a crisis as a national concern, political motives can take a central role (Warner \& Boas, 2017). Thus, metaphors have the capability to highlight some of the features of reality and conceal some other parts of it (Lakoff \& Johnson, 1980). Also, as Chilton and Lakoff (1995) argue, apparent and natural metaphors have the ability to contribute to legitimize a structure and justify policies and programmes. In turn, as Lakoff and Johnson (1980) have pointed out, 'People in power get to impose their metaphors.' This is especially true in the context of foreign policy. Social actors will try to use discursive strategies, including strategic labelling and narrative-making, to sell, legitimize or justify a specific policy or management strategy (Lindseth, 2005). Bisht (2011) has claimed the jihadist 'water war narrative' may well have a strategic rationale to silence the voices of the domestic opposition to the unequal distribution of land plan and inappropriate water laws in Pakistan.

Pakistan's water distribution policies reflect the dominance of Punjab in Pakistani politics and the intense rivalry exploited by political actors (Burgess et al., 2016). Politically and economically, the most significant province of Pakistan is Punjab. It comprises only $26 \%$ of Pakistan's land area but it has the most cropped and irrigated lands (Mustafa, 1998).

The Indian newspaper The Tribune wrote in 2010 that, 'Pakistan wanted to divert public attention from the recurring water scarcity in many parts due to mismanagement of its 
resources' (Menon, 2010). And to be clear, resource mismanagement cannot be regarded as just a structural weakness for Pakistan: it also applies to other South Asian states including India and Bangladesh (Price et al., 2014). But as Warner (2013) claimed in the context of the River Nile, it cannot be ruled out that water diversion can facilitate political diversion. An antiIndian water discourse may risk fuelling Pakistani's disengagement with the water issue, so that they may deny their water problems and not engage in solving them while some of Pakistan's water problems are related to mismanagement and other domestic reasons.

We do not predict that the two states will actually go to war due to the escalating securitizing process. However, securitization within the hostile context between the two countries from the separation of the two states in 1947 has reinforced an adversarial 'us versus them' dynamic. Therefore, any negotiation on Indian terms with water cannot be accepted by Pakistan's army and extremist groups who are two main players in Pakistan's politics. They have gained a strong influence on their society and relied on a 'war narrative' and strong metaphors against the Indian water activity on the Indus, which can arouse people's feelings against India. They have considered water issue inseparable from the issue of Kashmir (Rigi \& Warner, 2020). For instance, General Ashfaq Kayani, who regarded both the water and Kashmir as unresolved issues with India, stated that 'India will remain the focus of Pakistani military doctrine so long as Pakistan has unresolved issues with India' (Gupta, 2010). The collapse of negotiations on the Ratle project is one example how this project ended in tension due to attacks in India during negotiations between Pakistan and India (Economic Times, 2017).

Moreover, although just the grammar of the metaphor may not affect India, so that Indians may not take them seriously. Its hate speeches in turn may strengthen the hawks' position in India as they may also be useful in motivating Indian domestic audiences' antiPakistan passions (domestic consumption), while undermining the position of those who support a dialogue with Pakistan. The effect is to kill off opening a dialogue between the two countries.

\section{Conclusions}

In this paper we set out to show how Pakistan represents the diversion of Indus waters as a security threat through its linguistic practices (based on the English language sources available to us).

Water can easily become a flashpoint in a context where interstate relations are already fraught (Warner et al., 2008). Following Wolf (1995), we may reiterate that no countries have gone to war only over water, and despite all the bellicose rhetoric of recent years, we see little reason to anticipate a change in that situation. The metaphors we identified could therefore be dismissed as political performance, as theatrics. The threats and metaphors, however, can serve a different purpose. As Katz (2011) notes, the hyperbole has an effective signalling function in the realm of diplomacy; to each other ('don't mess with us'), but as Sneddon and Fox (2006) have noted, also to others in the development domain, as highly visible threats of water war also attract international attention and funding seeking to avert conflict escalation, such as the Nile Basin Initiative. Most of all, however, they seem to be aimed at rallying the domestic audience.

Indeed, the separation of British India into India and Pakistan in 1947 and the (geo) political disputes between the two countries, as well as the several wars between the two 
countries, provided the essential socio-political grounds for the identification of 'the enemy-other' in the minds of both sides which caused the two sides to consider the other as a threat. Within this framework, the discourses of Indo-phobia and Pakistanphobia have been formed, which have made the low politics-related issues enter easily into the high politics domain and be securitized.

The statements from Pakistani officials have shown how linguistic constructs used in the water realm can securitize water and move it into the 'high politics' arena, and how a securitization discourse framed the shared river and India's water activity as a threat that posed detrimental consequences to Pakistan.

The findings of this study show that Pakistan has been able to represent India's water activities as hostile activities, as well as existential and immediate threats to the security of Pakistan and its society through using linguistic constructs such as (security) framing, and a set of metaphors. Metaphors often use 'alarming' language to display a serious danger, which requires emergency actions. India's current leadership seems only too happy to reinforce the perception of India using the Indus as an instrument of power, vindicating Pakistan's worst fears and lending 'felicity' to the entrenched water war discourse. As such hostile statements are made in widely read media in the public domain, they are bound to be picked up.

The linkage between specific concepts, experiences and historical events in the historical mentality of Pakistani society has caused this discourse to be strengthened in that society. Conflating water security with the Kashmir issue, as well as metaphorical structures used in the transboundary water domain, which to a great extent overlap with the foreign policy of Pakistan in representing India as a vital threat, has strengthened the Indo-phobic discourse in the water realm, which can be considered a major obstacle to cooperation between the two countries on the water domain. Thus, the securitization of transboundary waters in areas where there is a long-standing geopolitical dispute can complicate cooperation between the two countries on water issues.

\section{Disclosure statement}

No potential conflict of interest was reported by the authors.

\section{ORCID}

Jeroen F. Warner (D) http://orcid.org/0000-0003-2847-8770

\section{References}

Abbott, D. H. (2010). The handbook of (5GW): A fifth generation of war. Nimble.

Akhter, M. (2016). Water security in South Asia between state and society. Georgetown Journal of Asian Affairs, 3(1),37-41.https://issuu.com/georgetownsfs/docs/gjaa_vol.3_no.1

Allouche, J. (2005). Water nationalism: An explanation of the past and present conflicts in Central Asia, the Middle East and the Indian subcontinent? [Doctoral dissertation]. Université de Genève.

Allouche, J. (2010). The multi-level governance of water and state-building. A longue durée perspective. In K. Wegerich and J. Warner (Eds.), The politics of water: A survey (pp. 45-67). Routledge. 
Assam Tribune. (2016, November 26). River flow to Pak will be stopped: PM. http://www.assamtribune. com/at/2016/nov2616/AllPagesAT.pdf

Bakshi, G., \& Trivedi, S. (2011). The Indus equation. Strategic Foresight Group.

Balzacq, T. (2005). The three faces of securitization: Political agency, audience and context. European Journal of International Relations, 11(2), 171-201. https://doi.org/10.1177/1354066105052960

Balzacq, T. (2007). The policy tools of securitization: Information exchange, EU foreign and interior policies. JCMS: Journal of Common Market Studies, 46(1), 75-100. https://doi.org/10.1111/j.14685965.2007.00768.x

Baqai, H. (2017, January 23). A ticking water bomb between India and Pakistan. https://Www. Globalvillagespace.Com/Ticking-Water-Bomb-India-Pakistan/

Barendt, E. (2019). What Is the harm of hate speech? Ethical Theory and Moral Practice, 22(3), 539553. https://doi.org/10.1007/s10677-019-10002-0

Barua, A., Vij, S., \& Zulfiqur Rahman, M. (2018). Powering or sharing water in the Brahmaputra River basin. International Journal of Water Resources Development, 34(5), 829-843. https://doi.org/10. 1080/07900627.2017.1403892

Benea, C. B., \& Onița, A. S. (2017). Dams in time of water nationalism. In CBU international conference proceedings, Vol. 5, pp. 23-28).

Bhatnagar, A., \& Mohan, C. R. (2016). India-Pakistan relations and regional stability. In: Ahmad M, Banerjee D, Bhatnagar A, Fair C.C, Felbab-Brown V, Haqqani H, Karim M, Karim T A, Katju V, Mohan C. R, Nelson M J., and Ranade Jayadeva, Mapping Pakistan's internal dynamics: Implications for state stability and regional security. The National Bureau of Asian Research. NBR special report \#55. 2016. https://reliefweb.int/sites/reliefweb.int/files/resources/SR55_Mapping_Pakistan_February2016.pdf

Bhushan, B. (2018, March 29). Indus water treaty not a weapon against Pakistan. Bloomberg Quint. https://www.bloombergquint.com/opinion/indus-water-treaty-not-a-weaponagainstPakistan

Bisht, M. (2011). The politics of water discourse in Pakistan. ICRIER Policy Series, 4, 1-17. http://www. indiaenvironmentportal.org.in/content/337774/the-politics-of-water-discourse-in-pakistan/

Briscoe, J. (2010). Troubled waters: Can a bridge be built over the Indus? Economic and Political Weekly, 45(50), 28. https://Www.Independent.Co.Uk/News/World/Asia/India-Is-Stealing-WaterOf-Life-Says-Pakistan-1654291.html

Burgess, J. P., Owen, T., \& Sinha, U. K. (2016). Human securitization of water? A case study of the Indus waters basin. Cambridge Review of International Affairs, 29(2), 382-407. https://doi.org/10. 1080/09557571.2013.799739

Buzan, B., Waever, O., \& de Wilde, J. (1998). Security: A new framework for analysis. Lynne Reiner.

Cheema, M. J. (2015). Pakistan-India conflict with special reference to Kashmir. South Asian Studies, 30(1), 45. https://www.semanticscholar.org/paper/Pakistan-India-Conflict-with-SpecialReference-to-Cheema/e8e435b9fa675fe3e764df466a0e907993e44380

Chilton, P., \& Lakoff, G. (1995). Metaphor in foreign policy discourse in Christina Schaffner and A.L. Wenden, Eds, language and peace. Aldershot. https://climateemergencydeclaration.org/climateemergency-declarations-cover-15-million-citizens/

Cohen, S. P. (2001). India: Emerging power. Brooking Institution Press.

Crilly, R. (2010, April 27). Mumbai terrorist group threaten Indian 'water jihad'. The Telegraph. https:// www.telegraph.co.uk/news/worldnews/asia/india/7639449/Mumbai-terrorist-group-threatenIndian-water-jihad.html

D'Hanis, I. (2002). A logical approach to the analysis of metaphors. In L. Magnani \& N. Nersessian (Eds.), Logical and computational aspects of model-based reasoning (pp. 21-37). Kluwer Academic.

Daoudy, M. (2009). Asymmetric power: Negotiating water in the Euphrates and Tigris. International Negotiation, 14(2), 361-391. https://doi.org/10.1163/157180609X432860

Dar, Z. A. (2020). Theatrics of securitization in Kashmir: People, the state and Kashmir. Modern Diplomacy, March 8. https://moderndiplomacy.eu/2020/03/08/theatrics-of-securitisation-in-kash mir-people-the-state-and-kashmir/

Dawn (2009, September 7). Farmers protest Indian water aggression. Dawn. https://www.dawn.com/ news/947863 
Dawn (2016, November 25). Water belonging to India cannot go to Pakistan,' says Modi. Dawn. https://www.dawn.com/news/1298575

Dawn (2017, June 21) Pakistan wants friendly relations with India, says Sharif, Dawn. https://www. dawn.com/news/1316669

Deudeny, D. (1990). Environment and security: Muddled thinking. Bulletin of the Atomic Scientists, 47 (3), 21-28.

Ebrahim, Z. (2015), Pakistan's new plan to embrace floods. The Thirdpole, July 29. https://www. thethirdpole.net/2015/07/29/pakistans-new-plan-to-embrace-floods/

Economic Times. (2017), India permitted to construct Kishanganga, Ratle projects: World Bank. Economic Times, August 2.

Faizullaev, A. (2017). Symbolic insult in diplomacy: A subtle game of diplomatic slap. Brill Research Perspectives in Diplomacy and Foreign Policy, 2(4), 1-116. https://doi.org/10.1163/2405600612340008

Ferrari, F. (2007). Metaphor at work in the analysis of political discourse: Investigating a 'preventive war' persuasion strategy. Discourse \& Society, 18(5), 603-625. https://doi.org/10.1177/ 0957926507079737

Fischhendler, I. (2015). The securitization of water discourse: Theoretical foundations, research gaps and objectives of the special issue. International Environmental Agreements: Politics, Law and Economics, 15(3), 245-255. https://doi.org/10.1007/s10784-015-9277-6

Fischhendler, I., \& Katz, D. (2013). The use of 'security' jargon in sustainable development discourse: Evidence from UN commission on sustainable development. International Environmental Agreements: Politics, Law and Economics, 13(3), 321-342. https://doi.org/10.1007/s10784-012-9192-z

Francis, R. A. (2011). The impacts of modern warfare on freshwater ecosystems. Environmental Management, 48(5), 985. https://doi.org/10.1007/s00267-011-9746-9

Gazdar, H. (2005). Baglihar and the politics of water in Pakistan-A historical perspective from Pakistan. Economic and Political Weekly, 40(9), 813-817.

Gettleman, J. (2019). India threatens a new weapon against Pakistan: Water. The New York Times, February 21. https://www.nytimes.com/2019/02/21/world/asia/india-pakistan-water-kashmir. html

Gupta, A. (2010, March 29). Vicious anti-India propaganda in Pakistan on water issues. IDSA Comment. Manohar Parrikar Institute for Defence Studies and Analysis. https://idsa.in/idsacom ments/Viciousanti-IndiapropagandainPakistanonWaterissues_agupta_290310

Haq, I., \& Sofi, S. A. (2019). Kashmir conflict and Indus water treaty: An analysis. Kardan Journal of Social Sciences and Humanities, 2(2), 44-56. https://kardan.edu.af/data/public/files/KJSSH-2.2428122019012831.pdf

Heradstveit, D., \& Bonham, M. G. (2007). What the axis of evil metaphor did to Iran. The Middle East Journal, 61(3), 421-440. https://doi.org/10.3751/61.3.12

Hill, D. (2006). The politics of water in South Asia. Transforming Cultures eJournal, 1(2), 135-158. https://doi.org/10.5130/tfc.v1i2.255

Holbraad M., Pedersen, M.A. (2012). Revolutionary securitization: An anthropological extension of securitization theory. International Theory, 4(2). https://doi.org/10.1017/S1752971912000061

James, C. C., \& Özdamar, Ö. (2005). Religion as a factor in ethnic conflict: Kashmir and Indian foreign policy. Terrorism and Political Violence, 17(3), 447-467. https://doi.org/10.1080/ 09546550590929219

Kalis, N. A., \& Dar, S. S. (2013). Geo-political significance of Kashmir: An overview of Indo-Pak relations. IOSR Journal of Humanities and Social Science, 9(2), 115-123. https://doi.org/10.9790/ 0837-092115123

Katz, D. (2011). Hydro-political hyperbole: Examining incentives for overemphasizing the risks of water wars. Global Environmental Politics, 11(1), 12-35. https://doi.org/10.1162/GLEP_a_00041

Kaushik, A. K. (2017). Regulating water security in border regions: The case of India and Pakistan. MA Thesis, Law and Diplomacy Capstone Requirement.

Khalid, I. (2010). Trans-boundary water sharing issues: A case of South Asia. Journal of Political Studies, 1(2), 79-96. 
Khattak, D. (2018, August 21). Imran Khan's foreign policy approach. The Diplomat. https://thediplo mat.com/2018/08/imran-khans-foreign-policy-approach/

Kraska, J. (2003). Sustainable development is security: The role of transboundary river agreements as a confidence building measure (CBM) in South Asia. The Yale Journal of International Law, 28(2), 465-503. http://digitalcommons.law.yale.edu/yjil/vol28/iss2/11

Kumar Sinha, U. (2008). India and Pakistan: Introspecting the Indus treaty. Strategic Analysis, 32(6), 961-967. https://doi.org/10.1080/09700160802404471

Lakoff, G., \& Johnson, M. (1980). Metaphors we live by. University of Chicago Press.

Lakoff, G. J., \& Johnson, M. (2003). M.(1980). Metaphors we live by. Chicago/London: University of Chicago Press.

Lee, S. H. (2002). Conflict unending: India-Pakistan tensions since 1947. International Journal, Toronto, 57(4), 654-655. https://doi.org/10.2307/40203701

Lindahl, A., \& Sundset, V. (2003). The grammar of threat and security in HIV/AIDS - An analysis of the South African Government's discourse on HIV and AIDS between 1998-2002. Master's thesis, Linkoping, Sweden: Department of Management and Economics, Linkoping University.

Lindseth, G. (2005). Local level adaptation to climate change: Discursive strategies in the Norwegian context. Journal of Environmental Policy and Planning, 7(1), 61-83. https://doi.org/10.1080/ 15239080500251908

Looney, R. (2012). Economic impacts of the floods in Pakistan. Contemporary South Asia, 20(2), 225-241. https://doi.org/10.1080/09584935.2012.670203

Lorenzo-Dus, N., \& Marsh, S. (2012). Bridging the gap: Interdisciplinary insights into the securitization of poverty. Discourse \& Society, 23(3), 274-296. https://doi.org/10.1177/0957926511433453

Malik, M. Z., \& Tanveer, A. (2014). Pakistani Islamists use floods to turn opinion against India. Reuters, September 17. https://www.reuters.com/article/us-southasia-flood-militants/pakistani-islamistsuse-floods-to-turn-opinion-against-india-iduskbnOhb2it20140916

Malik, R. (2018). Water bomb shell. The Nation, June 9. https://nation.com.pk/09-Jun-2018/waterbomb-shell

Maqbool, S. A., \& Alam, M. B. (2016). The uncertain future of Afghanistan: Security perceptions in India \& Pakistan. The Journal of Political Science, 34, 73-79. https://www.tehqeeqat.org/down loadpdf/3107

Masood, S. (2010). India accused of waging water war. The National, April 5. https://www.thena tional.ae/world/asia/india-accused-of-waging-water-war-1.556900

Mazari, S. (2005). The Baglihar dam and the Indus water treaty. Strategic Studies, 25(1), 1-13.http:// www.cssforum.com.pk/css-compulsory-subjects/current-affairs/current-affairs-notes/18708-bagli har-dam-indus-water-treaty.html

Menga, F. (2015). Building a nation through a dam: The case of Rogun in Tajikistan. Nationalities Papers, 43(3), 479-494. https://doi.org/10.1080/00905992.2014.924489

Menga, F. (2016). Domestic and international dimensions of transboundary water politics. Water Alternatives, 9(3), 704-723. http://www.water-alternatives.org/index.php/alldoc/articles/vol9/ v9issue3/322-a9-3-17

Menon, M. S. (2010). A tribune special: Waters of discontent; India should press Pakistan for a review of the Indus waters treaty, says M.S. Menon. The Tribune, April 4. http://www.tribuneindia.com/ 2010/20100404/edit.htm\#1

Merchant, B. Apocalypse talk: How our best metaphors for collapse help us prevent it Vice, May 30, 2014, https://www.vice.com/en_us/article/78xxz4/finding-the-right-metaphor-for-apocalypse

Milliken, J. (1999). The study of discourse in international relations: A critique of research and methods. European Journal of International Relations, 5(2), 225-254. https://doi.org/10.1177/ 1354066199005002003

Mirumachi, N. (2013). Securitising shared waters: An analysis of the hydropolitical context of the Tanakpur Barrage project between Nepal and India. The Geographical Journal, 179(4), 309-319. https://doi.org/10.1111/geoj.12029

Mirza, M. N. (2016). Indus water disputes and India-Pakistan relations [Doctoral dissertation]. University of Heidelberg. 
Molle, F., Mollinga, P. P., \& Wester, P. (2009). Hydraulic bureaucracies and the hydraulic mission: Flows of water, flows of power. Water Alternatives, 2(3), 328-349. http://www.water-alternatives. org/index.php/alldoc/articles/vol2/v2issue3/65-a2-3-3

Mustafa, D. (1998). Structural causes of vulnerability to flood hazard in Pakistan. Economic Geography, 74(3), 289-305. https://doi.org/10.2307/144378

Mustafa, D., \& Wrathall, D. (2011). Indus basin floods of 2010: Souring of a Faustian bargain? Water Alternatives, 4(1), 72-85. http://www.water-alternatives.org/index.php/allabs/127-a4-1-5/file

Nadeem, M., Sayeed, S., \& Dasgupta, N. (2019). Pakistan, India spar over using water as a weapon in Kashmir dispute. Reuters, August 19. https://www.reuters.com/article/us-india-kashmir-pakistanwater/pakistan-india-spar-over-using-water-as-a-weapon-in-kashmir-dispute-idUSKCN1V91B9

Nagheeby, M., \& Warner, J. (2018). The geopolitical overlay of the hydropolitics of the Harirud River Basin. International Environmental Agreements: Politics, Law and Economics, 18(6), 839-860. https://doi.org/10.1007/s10784-018-9418-9

Nakash, Y. (1993). An attempt to trace the origin of the rituals of 'Āshūrā'. Die Welt des Islams, 33(2), 161-181. https://doi.org/10.2307/1570949

Nazakat Ali, R., \& Faiz-Ur-Rehman, M.-U.-R. W. (2015). Indus water treaty between Pakistan and India: From conciliation to confrontation. Dialogue (Pakistan), 10(2), 166-181. https://www.seman ticscholar.org/paper/Indus-Water-Treaty-between-Pakistan-and-India\%3A-From-Ali-Faiz-urRehman/23f7ea6ddfce5f18d8a7eed5b2bd731c5989b433

Neo, R. (2020). Religious securitization and institutionalized sectarianism in Saudi Arabia. Critical Studies on Security, 8(3), 203-222. https://doi.org/10.1080/21624887.2020.1795479

Office of the United Nations High Commissioner for Human Rights. (2008). Human rights, terrorism and counter-terrorism. United Nations, Victims of Terrorism Support Portal. Fact Sheet No. 32.

Osiur, R. (2015). An analysis of the regional security of South Asia in Post 9/11 period: Regional security complex theory approach [Master's thesis]. Eastern Mediterranean University/Doğu Akdeniz Üniversitesi.

Price, G., Alam, R., Hasan, S., Humayun, F., Kabir, M.H., Karki, C. S., Mittra, S., Saad, T., Saleem, M., Saran, S., Shakya, P. R., Snow, C., \& Tuladhar, S. (2014). Attitudes to water in South Asia. Royal Institute of International Affairs. https://www.chathamhouse.org/sites/default/files/field/field_ document/20140627WaterSouthAsia.pdf

Qadir, L. C. H. (2008). Water-a source of conflict in South Asia. NDU Journal, Il, 141-192. https://www. ndu.edu.pk/issra/issra_pub/articles/ndu-journal/NDU-Journal-2008/8_WATER_A_SOURCE_OF_ CONFLICT.pdf

Rahman, M. Z. (2014). Territory, roads and trans-boundary Rivers: An analysis of Indian infrastructure building along the Sino-Indian border in Arunachal Pradesh. Eurasia Border Review, 5(1), 59-75. https://eprints.lib.hokudai.ac.jp/dspace/handle/2115/57846

Reuters. (2019, August 19) Pakistan accuses India of waging 'fifth-generation warfare' in Kashmir by using water as weapon. https://www.scmp.com/news/asia/south-asia/article/3023486/pakistanaccuses-india-waging-fifth-generation-warfare-kashmir

Riffat, F., \& Iftikhar, A. (2015). Water issues and its implications Over India-Pakistan relations. Journal of the Punjab University Historical Society), 28(2). https://prdb.pk/article/water-issues-and-its-impli cations-over-india-pakistan-relati-9684

Rigi, H., \& Warner, J. (2020). Two-level games on the trans-boundary river Indus: Obstacles to cooperation. Water Policy, 22(6), 972-990. https://doi.org/10.2166/wp.2020.090

Rivière, D. (2015). Thirsty Elephant-India's water security challenges: A test for regional relations over the next decade. The Centre for Defence and Strategic Studies (CDSS), Australian Defence College

Romshoo, A. S. (2012). Indus River basin common concerns and the roadmap to resolution. Centre for Dialogue and Reconciliation, New Delhi. https://docplayer.net/95798809-Indus-river-basin-com mon-concerns-and-the-roadmap-to-resolution-author.html

Salter, M. (2008). Securitization and desecuritization: A dramaturgical analysis of the Canadian air transport security authority. Journal of International Relations and Development, 11(4), 321-349. https://doi.org/10.1057/jird.2008.20

Selby, J. (2003). Water, power and politics in the Middle East: The other Israeli-Palestinian conflict (25). I. B. Tauris. 
Sharma, P. K. (2012). Conflict over water between India and Pakistan: Fear and hopes? Indian Journal of Political Science, 73(1), 133-140.

Sheikh, M. K. (2018). Recursion or rejection? Securitization theory faces Islamist violence and foreign religions. Global Discourse 8(1), 26-38. https://doi.org/10.1080/23269995.2017.1411644

Singh, R. (2008). Trans-boundary water politics and conflicts in South Asia: Towards 'water for peace'. A report of centre for democracy and social action. Centre for Democracy and Social Action.

Sneddon, C., \& Fox, C. (2006). Rethinking transboundary waters: A critical hydropolitics of the opportunities. IOSR Journal of Humanities and Social Science, 20(12), 181-202. https://doi.org/ 10.9790/0837-201250712

Sugunakararaju, D.S., \& Akhtar, S. (2015). India-Pakistan relations: Challenges and opportunities. IOSR Journal of Humanities and Social Science, 20(12). https://doi.org/10.9790/0837-201250712

Telegraph. (2009). Pakistan accuses India of stealing water. The Telegraph, March 26. http://www. telegraph.co.uk/news/worldnews/asia/pakistan/5052150/pakistan-accuses-india-of-stealingwater.html

Torfing, J. (1999). New theories of discourse: Laclau, Mouffe, and Zizek. Blackwell.

Vaid, M., \& Maini, T. S. (2012). Indo-Pak water disputes: Time for fresh approaches. South Asian Journal of Peace Building, 104(2).

Waldron, J. (2012). The harm in hate speech. Harvard University Press.

Warner, J. (2004). Plugging the GAP-working with Buzan: The llisu dam as a security issue. Occasional Paper, 67. School of Oriental and African Studies.

Warner, J. (2013). The Toshka mirage in the Egyptian desert-River diversion as political diversion. Environmental Science \& Policy, 30(6), 102-112. https://doi.org/10.1016/j.envsci.2012.10.021

Warner, J., \& Boas, I. (2017). Securitisation of climate change: The risk of exaggeration. Ambiente \& Sociedade, 20(3), 203-224. https://doi.org/10.1590/1809-4422asocex0003v2022017

Warner, J., \& van Buuren, A. (2011). Implementing room for the river: Narratives of success and failure in Kampen, the Netherlands. International Review of Administrative Sciences, 77(4), 779-801. https://doi.org/10.1177/0020852311419387

Warner, J., Wester, P., \& Bolding, A. (2008). Going with the flow: River basins as the natural units for water management? Water Policy, 10(S2), 121-138. https://doi.org/10.2166/wp.2008.210

Wellen, R. (2011, December, 13). Will Pakistan counter India's "water bomb" with a nuclear bomb? https://fpif.org/will_pakistan_counter_indias_water_bomb_with_a_nuclear_bomb/

Wescoat, J., Jr, Halvorson, S. J., \& Mustafa, D. (2000). Water management in the Indus basin of Pakistan: A half-century perspective. International Journal of Water Resources Development, 16(3), 391-406. 10.1080/71367250. https://doi.org/10.1080/713672507

Wilkinson, C. (2007). The Copenhagen School on tour in Kyrgyzstan: Is securitization theory useable outside Europe?. Security Dialogue, 38(1), 5-25. https://doi.org/10.1177/0967010607075964

Wirsing, R. G. (2008). Rivers in contention: Is there a water war in South Asia's future? Heidelberg papers in South Asian and comparative politics. Working Paper No. 41

Wirsing, R. G., \& Jasparro, C. (2007). River rivalry: Water disputes, resource insecurity and diplomatic deadlock in South Asia. Water Policy, 9(3), 231-251. https://doi.org/10.2166/wp.2007.014

Wolf, A. T. (1995). Hydropolitics along the Jordan River: Scarce water and its impact on the Arab-Israeli conflict (Vol. 99). United Nations University Press.

Zeitoun, M., \& Warner, J. (2006). Hydro-hegemony - A framework for analysis of trans-boundary water conflicts. Water Policy, 8(5), 435-460. https://doi.org/10.2166/wp.2006.054 